\title{
The content of fulvic acids in the primary effluent at the Płaszów WWTP in Kraków
}

\author{
Dominika Łomińska ${ }^{1,{ }^{*}}$, and Anna M. Anielak ${ }^{1}$ \\ ${ }^{1}$ Department of Environmental Engineering, Institute of Water Supply and Environmental Protection, \\ Cracow University of Technology, 24 Warszawska, 31-155 Cracow, Poland
}

\begin{abstract}
Municipal wastewater contains significant amounts of organic substances of both natural and anthropogenic origin. Wastewater treatment removes most of contaminants, however new substances are formed as a result of biochemical changes taking part during the treatment process; some of them remain in the final effluent and may pose a threat to life and health of living organisms. Humic substances (HS), which include soluble fulvic acids (FA) are contaminants commonly found in wastewater. This is why the research attempted to examine the content of fulvic acids in mechanically treated wastewater at the Płaszów Wastewater Treatment Plant (WWTP) in Kraków. The study was conducted to assess the quantities of the pollution load coming to the plant. FA were separated (isolated) at a hydrophobic ion exchanger, and then subjected to qualitative analysis to determine their elemental composition and degree of contamination with metals and other substances. Studies were also conducted in the infrared spectrum to determine the effects of internal structure of fulvic acids. Humic acids (HA) are precursors of chloroorganic compounds and other carcinogenic, mutagenic and teratogenic substances in oxidation and disinfection processes. Therefore the problem of FA in the final effluent is important, because of their amount and location of a wastewater discharge point.
\end{abstract}

\section{Introduction}

According to a lot of authors humic substances (HS) are the most widely distributed organic materials in the environment [1]. HS are natural products resulting from decomposition of organic matter (plants and animals) found in soils, sediments and natural waters. Their colour depends on their origin, concentrations and $\mathrm{pH}$ of the solution; it may change from yellow to dark brown. The molecular weight of HS ranges from a few hundred to a few thousand Daltons [2, 3]. In general HS are a mixture of different organic molecules. Although they have been known for over 200 years, their permanent chemical structure have not been established yet, and many models of their structure are known [4]. Their chemical form depends on: conditions under which process of peat runs, hydration of the local environment, type and duration of humification [5]. This is closely connected with a variety of their physicochemical properties.

* Corresponding author: dominika.lominska@pk.edu.pl 
Humic substances can be classified according to their solubility as: humic acids (HA), fulvic acids (FA), hymatomelanic acids and humin. HA dissolve in alkaline solution and precipitate in a strongly acidic conditions $(\mathrm{pH}<2)$. FA dissolve in both alkaline and acid solution while humin remain insoluble in acids and alkalis. Hymatomelanic acids (ulmine) dissolve in ethanol $[2,4]$. Quite often HA predominate in dissolved organic matter (DOM), as represented mainly by FA, which constitute approx. $50 \%$ of the DOM in aquatic ecosystems. The most important fraction, natural organic matter (NOM), comprises humic and fulvic acids, due to their solubility $[6,7]$.

The subject of the research - FA are a fraction of humus compounds soluble in water, $\mathrm{NaOH}$ solution and diluted acids. Their colour is from yellow to yellowish brown. Like HA their construction is not exactly known yet. It is believed that fulvic acid molecules create benzene rings linked in a polymer structure using a visa hydrogen $[8,9]$. Because of the fact that FA are smaller and have more carboxyl groups, they are much more chemically reactive than HA [10]. The elementary composition of FA is as follows: carbon $40-50 \%$, oxygen $44-50 \%$, and nitrogen $1-3 \%$ [11]. According to Ukrainian researchers, ,FA are major constituents of humic substances; their amount may reach $81-95 \%$ of the total HS' $[6,7]$. Since HS have a high content of functional groups and a high resistance to biodegradation they play an important role in both aquatic and land environments. Additionally, HS as natural organic acids are source of organic carbon for plants and microorganisms as well as play an important role in a biogenic cycle. They also take part in biochemical and nutrient involving processes [6, 7, 12]. In 1974 the researchers showed that HS may serve as precursors of carcinogenic and mutagenic compounds produced during oxidation and disinfection processes. They include: trihalomethanes (THM), haloacetic acids, halogenonitriles, halogenoketones, trichlorophenol, trichlorobenzenes, hydroxi-furanes and others. HS easily create soluble metal complexes which are hard to remove. During oxidation that is often used at the beginning of technological treatment system, they create by-products of oxidation which are much harder to remove that just HS. Therefore it should be aim to minimalize their concentration in water which is subjected to purification processes. This is the reason why HS should be studied in the environment and eliminated from water before entering a water treatment plant, otherwise they could pose a serious threat to the whole environment [13]. As it was reported by Pempkowiak [14] HA found in the effluent from the municipal wastewater treatment plant are different from HA isolated from the Vistula River. It means that municipal wastewater treatment plants are one of the sources of HS formation. Concentrations of HA in surface waters range from 1 to $9 \mathrm{mg} / \mathrm{dm}^{3}$ and the wastewater treatment plant effluent discharge may have a significant impact on a surface water quality [14]. The next very important thing is a fact that FA are introduced with raw sewage to WWTP as not biodegradable compounds, so they are largely discharged with effluent. Previous studies other authors have shown that some amounts of FA are discharged with treated sewage. Taking into account in the above facts the authors examined the content of FA in a mechanically treated wastewater (primary effluent) from the Płaszów WWTP in Kraków in order to obtain information whether these substances are introduced to wastewater treatment plants and to receive knowledge in which quantities.

\section{Materials and methods}

FA were extracted according to the method described in [15]. Then FA were examined by qualitative analysis to determine the elemental composition of acids and the degree of contamination with heavy metals and other substances. Studies were also carried in the infrared spectrum to determine an internal structure of FA. The analysis were performed in the certified laboratory EkotechLAB in Gdańsk. 


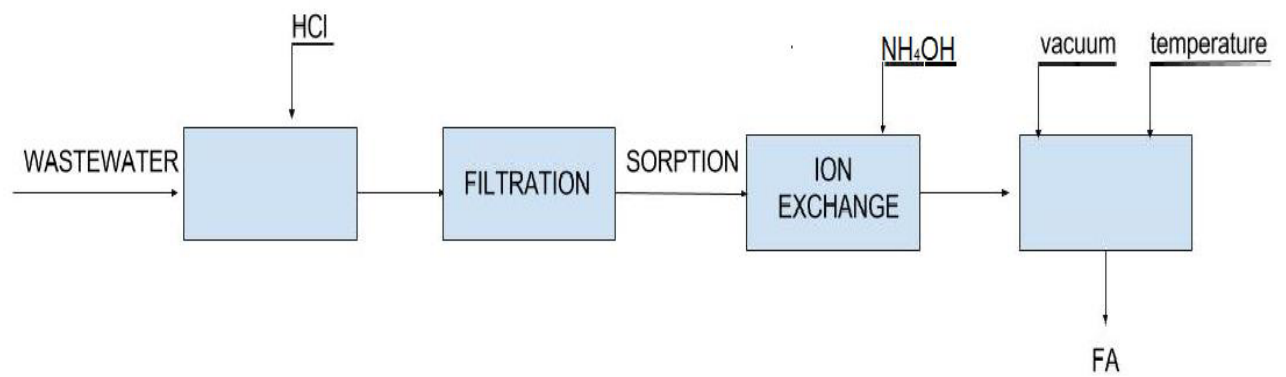

Fig. 1. Extraction of FA from wastewater at the Płaszów WWTP.

\subsection{Analytical methods}

The analysis of an elemental composition $(\mathrm{C}, \mathrm{H}, \mathrm{N}$ and $\mathrm{P})$ of $\mathrm{FA}$ was performed by the EkotechLab laboratory according to own research procedures. The analysis of carbon, hydrogen and nitrogen was carried out using a combustion technology with chromatography detection (elemental analysis) and samples of 5-10 mg. The analysis of other elements was performed using X-ray fluorescence technique (XRF). The studies were carried out in the vessel for powder analysis, on a Prolen film of a thickness of $4 \mu \mathrm{m}$. The research was conducted on the WD-XRF spectrometer, model S8 Tiger manufactured by Bruker and elemental analyzer Flash EA manufactured by Thermo.

EkotechLab laboratory performed thermogravimetric method according to the own research procedure. An ash content was determined using a thermogravimetric method at a heating rate of $50^{\circ} \mathrm{C} / \mathrm{min}$ up to $700^{\circ} \mathrm{C}$, then $700^{\circ} \mathrm{C}$ by 5 minutes at the air flow of $100 \mathrm{~mL} / \mathrm{min}$. The analysis was conducted on the thermogravimetr SDT Q600 manufactured by TA Instruments.

Identification of the compounds was performed using a FTIR technique with the ATR accessory. Spectral range was as follows: $650-4000 \mathrm{~cm}^{-1}$ with resolution of $1 \mathrm{~cm}^{-1}$, the scan number: 32 . The study was conducted on the FT-IR IS10 spectrometer manufactured by Thermo Nicolet.

\subsection{Wastewater treatment plant characteristic}

The Płaszów WWTP is located in the south-eastern part of Kraków in the Podgórze district, and it covers the area of 50 ha.
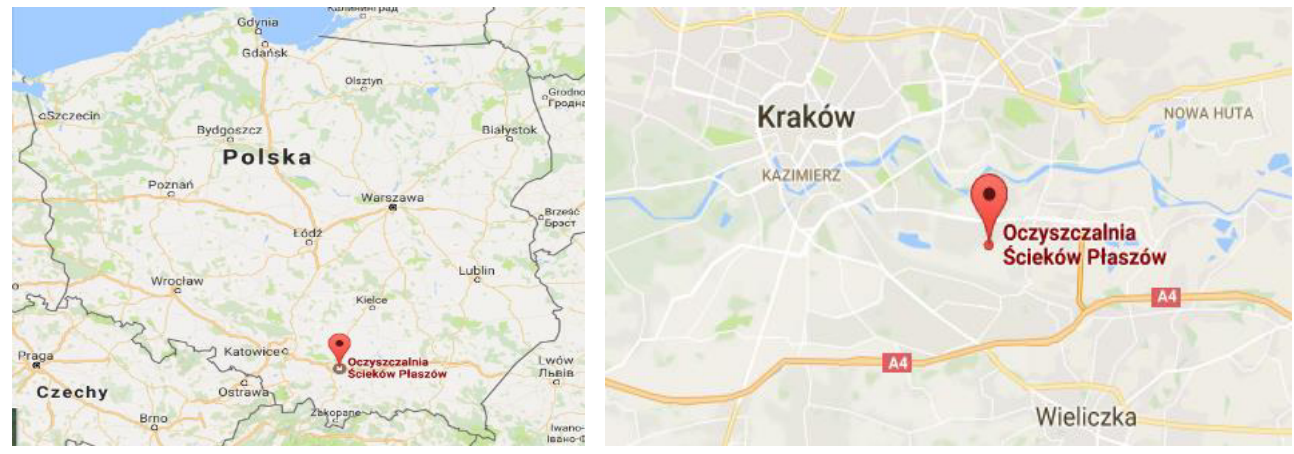

Fig. 2. Location of the Płaszów WWTP (Source: https://maps.google.com). 
The wastewater treatment plant treats mainly wastewater from industrial plants as well as from individual users. The Płaszów WWTP comprises mechanical and biological wastewater trains as well as sludge processing and biogas trains. The mechanical stage consists of: coarse bar screens, pumping station, fine bars screens, grit chambers, preliminary clarifiers and a second pumping station. The biological stage consists of biological reactors and secondary clarifiers. The sludge processing train includes: mechanical thickeners, sludge disintegration unit, gravity thickeners, belt presses, anaerobic digesters and a biogas generation train (biogas desulphurization, biogas tanks and boilers). The wastewater treatment plant effluent is discharged through the outlet cascade into the Drwina river. The plant works as a three stage Bardenpho system and operates five identical biological reactors. The wastewater treatment process comprises the following unit processes: pre-denitrification, biological phosphorus removal, nitrification and denitrification. The average wastewater flow is 165 thousand $\mathrm{m}^{3} /$ day while a capacity of a biological stage is 320 thousand $\mathrm{m}^{3} /$ day. The concentration of activated sludge ranges from 3.5 to $5.5 \mathrm{~kg}$ of dry solids $/ \mathrm{m}^{3}$. Excess sludge together with the primary sludge, after thickening to a $5 \%$ solid content, is pumped to the anaerobic digesters (information acquired at the Płaszów WWTP), [16].

\section{Results and discussions}

On the basis of data obtained from the Płaszów WWTP the authors [17] determined the parameters of wastewater entering the biological stage (primary effluent). The concentrations of $\mathrm{BOD}_{5}$ in the primary effluent remained within the range $212 \pm 72 \mathrm{mg} \mathrm{O}_{2} / \mathrm{L}$ while the COD concentrations were $422 \pm 170 \mathrm{mg} \mathrm{O} / \mathrm{L}$. A high content of nitrogen was observed, $\mathrm{N}_{\text {tot }} 56 \pm 12 \mathrm{mg} \mathrm{N} / \mathrm{L}$ while the concentration of $\mathrm{P}_{\text {tot }}$ was $5.7 \pm 1.7 \mathrm{mg} \mathrm{P} / \mathrm{L}$ [17].

The study involved analysis of FA extracted from primary effluent at the Płaszów WWTP with the characteristics as follows: $\mathrm{COD}=240.72 \mathrm{mg} \mathrm{O} / \mathrm{L}, \mathrm{N}_{\text {tot }}=64.96 \mathrm{mg} \mathrm{N} / \mathrm{L}$ and $\mathrm{P}_{\text {tot }}=6.37 \mathrm{mg} \mathrm{P} / \mathrm{L}$.

Table 1. Characteristic of the primary effluent (with extracted FA) from two separate studies.

\begin{tabular}{|c|c|c|}
\hline Parameter & $\begin{array}{c}\text { Primary effluent } \\
\text { (authors data) }\end{array}$ & $\begin{array}{c}\text { Primary effluent } \\
\text { [17] }\end{array}$ \\
\hline $\mathrm{COD} \mathrm{mg} \mathrm{O}_{2} / \mathrm{L}$ & 240.72 & $422 \pm 170$ \\
\hline $\mathrm{BOD}_{5} \mathrm{mg} \mathrm{O} 2 / \mathrm{L}$ & - & $212 \pm 72$ \\
\hline $\mathrm{N}_{\text {tot }} \mathrm{mg} \mathrm{N} / \mathrm{L}$ & 64.96 & $56 \pm 12$ \\
\hline $\mathrm{P}_{\text {tot }} \mathrm{mg} \mathrm{P} / \mathrm{L}$ & 6.37 & $5.7 \pm 1.7$ \\
\hline
\end{tabular}

The wastewater samples had a volume of $50 \mathrm{~L}$ (mechanically treated wastewater). Characteristics of fulvic acids (elemental composition) are shown in Table 2 and 3 . The acids isolated at a concentration of $14.8 \mathrm{mg} / \mathrm{L}$ had a dark brown colour. They were contaminated with inorganic substances $(\mathrm{Cl}, \mathrm{Si}, \mathrm{Na}, \mathrm{Ca}, \mathrm{K}, \mathrm{P}, \mathrm{Mg}$, and $\mathrm{Fe}, \mathrm{Br})$. The ash content was $11.55 \%$, which indicated a large amount of inorganic impurities. 


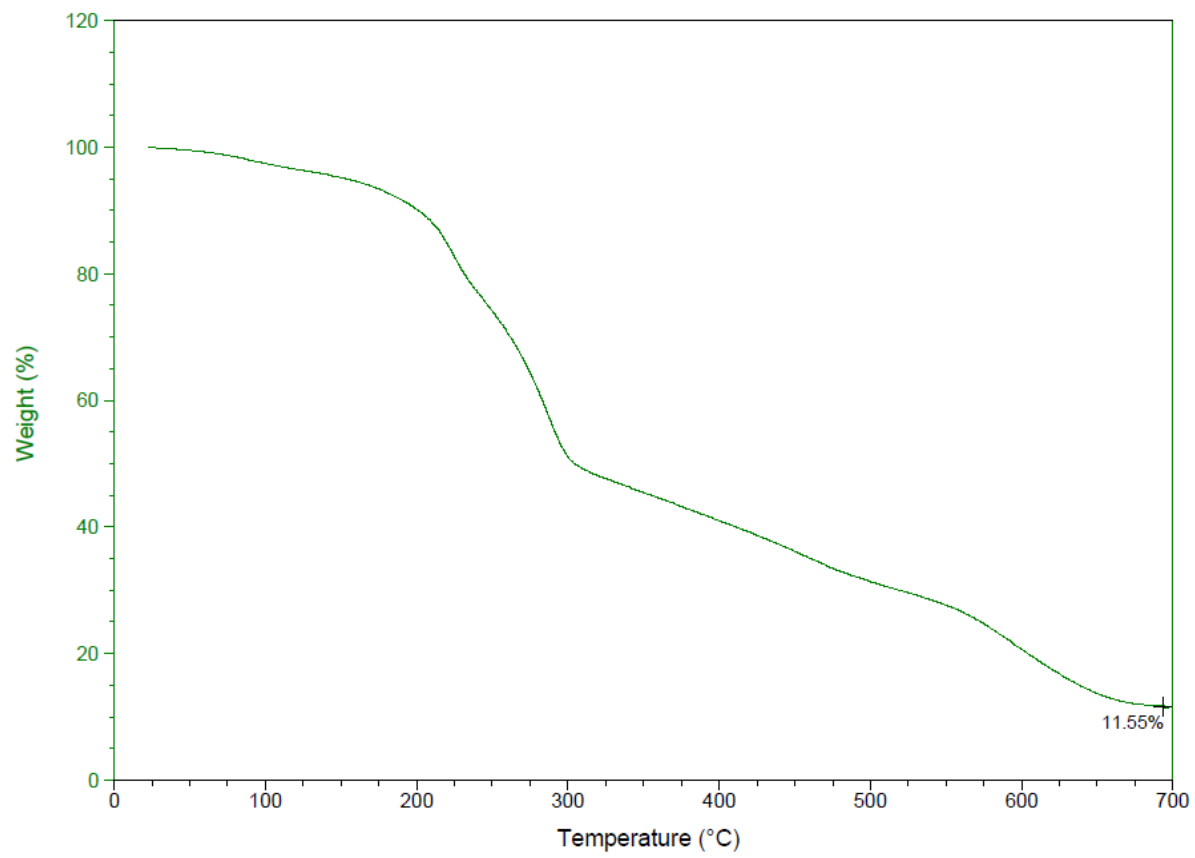

Fig. 3. Mass reduction in wastewater sample (after primary treatment) as a function of temperature.

Looking at the curve it can be seen that the sample mass decreases rapidly along with a temperature rise. At the ash content of $11.55 \%$ the sample weight remained unchanged, despite the temperature rise up to $700^{\circ} \mathrm{C}$. The mass remained constant at a temperature of approx. $680^{\circ} \mathrm{C}$, which was slightly higher than the temperature specified in the applicable standards $\left(550^{\circ} \mathrm{C}\right)$. The elemental composition of FA extracted from the effluent is shown in Table 1.

Table 2. Elemental composition of FA extracted from the primary effluent.

\begin{tabular}{|c|c|}
\hline $\begin{array}{c}\text { Element } \\
\text { (in ash-free mass) }\end{array}$ & $\begin{array}{c}\text { Content } \\
{[\%]}\end{array}$ \\
\hline $\mathrm{C}$ & 33.24 \\
\hline $\mathrm{H}$ & 4.60 \\
\hline $\mathrm{N}$ & 10.03 \\
\hline $\mathrm{S}$ & 1.87 \\
\hline $\mathrm{O}$ & 50.26 \\
\hline
\end{tabular}

Table 3. Ash content and atomic ratios in FA extracted from the primary effluent.

\begin{tabular}{|c|c|c|c|c|c|}
\hline \multirow{2}{*}{ Sample } & $\mathbf{C} / \mathbf{O}$ & $\mathbf{C} / \mathbf{H}$ & $\mathbf{C} / \mathbf{N}$ & Ash & FA \\
\cline { 2 - 6 } & {$[-]$} & {$[-]$} & {$[-]$} & {$[\%]$} & $\mathrm{mg} / \mathrm{L}$ \\
\hline Primary effluent & 0.66 & 7.23 & 3.31 & 11.55 & 14.81 \\
\hline
\end{tabular}


Table 4. Trace elements content in FA extracted from the primary effluent.

\begin{tabular}{|c|c|c|c|c|c|c|c|c|}
\hline \multirow{1}{*}{} & \multicolumn{9}{|c|}{ Elements } \\
\cline { 2 - 9 } & $\mathrm{Cl}$ & $\mathrm{Si}$ & $\mathrm{Na}$ & $\mathrm{Ca}$ & $\mathrm{K}$ & $\mathrm{Mg}$ & $\mathrm{P}$ & $\mathrm{Fe}$ \\
\cline { 2 - 9 } & {$[\%]$} & {$[\%]$} & {$[\%]$} & {$[\%]$} & {$[\%]$} & {$[\%]$} & {$[\%]$} & {$[\%]$} \\
\cline { 2 - 9 } $\begin{array}{c}\text { Primary } \\
\text { effluent }\end{array}$ & 13.62 & 2.58 & 1.74 & 0.93 & 0.37 & 0.29 & 0.28 & 0.04 \\
\hline
\end{tabular}

The main components of extracted FA are: oxygen which content in ash-free mass is $50.26 \%$ and carbon in an amount of $33.24 \%$. According to [18] a high oxygen content in the structure of FA may indicate the presence of carboxyl, carbonyl, methoxy, hydroxyl, alcohol, ester and steering groups [18]. According to table 2 hydrogen content is $4.60 \%$, sulfur content is 1.87 while a nitrogen content is $10.03 \%$. The high content of nitrogen may indicate the presence of amino acids in their structure. According to table 3 the $\mathrm{C} / \mathrm{N}$ ratio is relatively small and equals 3.31 due to a high nitrogen content in FA (10.03\%). The $\mathrm{C} / \mathrm{O}$ ratio provides information on acids hydrophobicity. The more carbon the greater the ratio and the greater hydrophobicity of the acids. The $\mathrm{C} / \mathrm{O}$ ratio for the $\mathrm{FA}$ from the wastewater was 0.66 , so it can be concluded that the acids extracted from the mechanically treated wastewater were hydrophilic and had a lot of functional groups. Another issue is the $\mathrm{C} / \mathrm{H}$ ratio, which served as an indicator of aromatization and condensation of HA. According to Pempkowiak the $\mathrm{C} / \mathrm{H}$ ratio in $\mathrm{HA}$ isolated from the marine environment was below 10, while for a regular land humus it was above 10 [14]. The $\mathrm{C} / \mathrm{H}$ ratio in $\mathrm{FA}$ from the primary effluent was 7.23 (below 10), so they seem to be less aromatized and condensed than the ones from the regular land humus. According to Table 4 a trace element of the largest content in FA extracted from the wastewater was chlorine (13.62\%), next was silica $(2.58 \%)$ and then sodium $(1.74 \%)$.

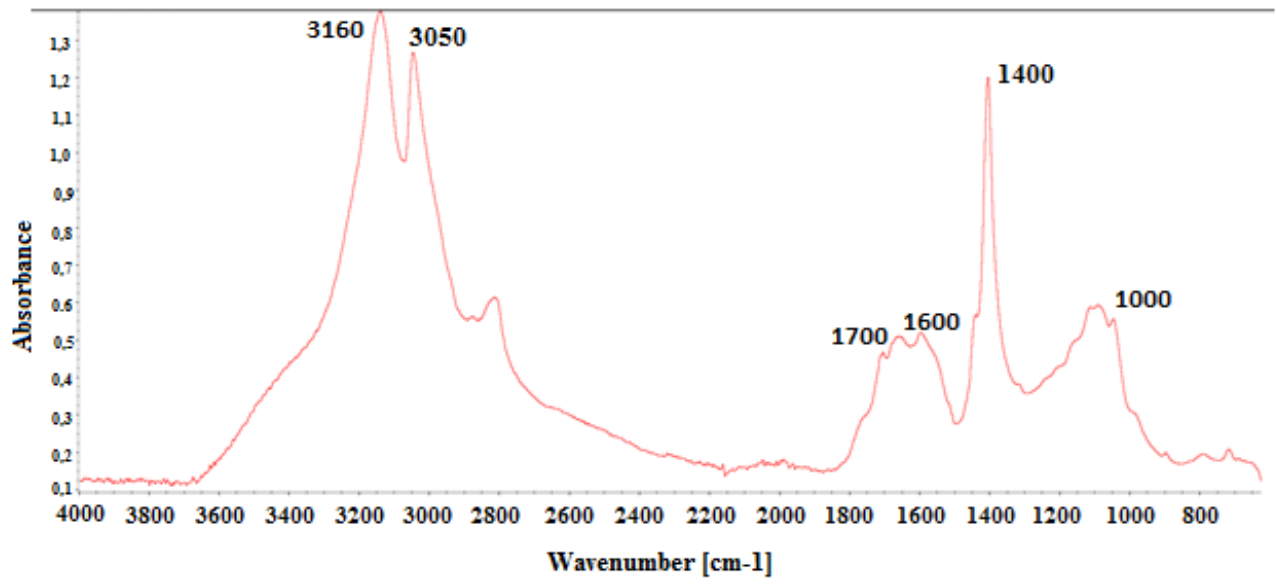

Fig. 4. The IR absorption spectra of FA separated from the primary effluent.

The IR absorption spectra of FA were conducted to analyse their structure. The analysis was performed based on the work [19, 20, 21, 22]. A spectral range was characteristic for this kind of substances: $650-4000 \mathrm{~cm}^{-1}$. A quite broad peak appeared around $3160 \mathrm{~cm}^{-1}$ that was usually attributed to $\mathrm{O}-\mathrm{H}$ stretching from alcohols, phenols and carboxylic related groups and also N-H stretching from amide and amince functional groups. The next peak around $3050 \mathrm{~cm}^{-1}$ was caused by $\mathrm{C}-\mathrm{H}$ asymmetric and symmetric stretching aromatic compounds. The peak around $1700 \mathrm{~cm}^{-1}$ and $1600 \mathrm{~cm}^{-1}$ can be attributed to the $\mathrm{C}=\mathrm{C}$ and 
$\mathrm{C}=\mathrm{O}$ stretching vibrations, coming from aromatic rings and carboxylic, ketone or ester groups repsectively. The peaks from $1400 \mathrm{~cm}^{-1}$ to $1000 \mathrm{~cm}^{-1}$ are probably due to $\mathrm{C}-\mathrm{O}$ stretching and $-\mathrm{CH}_{3}$ deformation vibartions. According to authors $[19,20,21,22]$ the complex heterogeneous nature of FA samples give rise to rather broad peaks observed $[19,20,21,22]$, what exactly the same has been observed in analysis of the primary effluent.

\section{Conclusions}

The primary effluent from the Płaszów WWTP was analysed for a presence of fulvic acids. FA isolated at a concentration of $14.8 \mathrm{mg} / \mathrm{L}$ had a deep brown colour and a high ash content $(11.55 \%)$, which indicates their considerable contamination with inorganic substances. FA extracted from the primary effluent at the wastewater treatment plant comprise carbon, nitrogen, hydrogen, and oxygen, which is symptomatic for FA.

Based on the IR spectrum analysis it was concluded that FA extracted from the primary effluent have a characteristic comparable with FA extracted from surface waters (Oyster River and Suwannee River) from soil [19, 20, 21] and from Kołobrzeg mud [11, 13].

The plant effluent complies with the applicable legal standards. According to the data published in the Statistical Yearbook of the Republic of Poland (2016), 8 827,8 million $\mathrm{m}^{3}$ of wastewater was discharged directly from wastewater treatment plants in 2015, including 514,3 million $\mathrm{m}^{3}$ of wastewater treated only in mechanical processes [23]. FA that are introduced with raw sewage to wastewater treatment plants, as not biodegradable compounds, are largely discharged with the effluent. Assuming that the FA concentrations are like in the primary effluent, their load discharged to the receiving water can be easily calculated. In 2015 in Poland there were 20 mechanical sewage treatment plants and their total capacity was $900000 \mathrm{~m}^{3} / \mathrm{d}$ [23]. The average concentration of FA in the primary effluent is approx. $15 \mathrm{~g} / \mathrm{m}^{3}$ so the daily load calculated based on the data from the Statistical Yearbook is significant and amounts to 13.5 tons/day. While the average wastewater flow in Płaszów WWTP at Kraków is 165 thousand $\mathrm{m}^{3} /$ day and the concentration of FA is $14.8 \mathrm{~g} / \mathrm{m}^{3}$, so the daily load can be calculated approx. 2.4 tons/day. FA are the most mobile components and that is why we usually have to deal with them and they become the most problematic issue.

The main goal of the study was to complete a balance and assess the amount of fulvic acids in the primary effluent at the Płaszów WWTP in Kraków. The studies have shown high concentrations of FA in primary effluent; they can penetrate into the surface waters and serve as precursors of oxidation and disinfection by-products at surface water treatment plants. The obtained results indicate necessity to carry out detailed analysis of the amount of discharged HS in specific biological reactor processes.

\section{References}

1. M. Kalina, M., Klučáková., P. Sedláček, Geoderma 207-208, 92-98 (2013)

2. Noel E. Palmer Ray von Wandruszka, Fresenius J Anal Chem 371, 951-954 (2001)

3. S.S. Gonet, B. Debska, A. Zaujec, In: Clapp CE, Hayes MHB, Senesi N, Griffith SM (eds), International Humic Substances Society, St Paul, MN, 95-101 (1996)

4. A.M. Anielak, Wysokoefektywne metody oczyszczania wody. PWN, Warszawa, 28-32 (2015) 
5. M. Drobnik, T. Latour, The Influence of Thermal Aand Chemical Processes on The Content and Structure of Humic Acids - The Basic Ingredient of Peat Preparations, ROCZN. PZH, 62, 4, 453 - 462 (2011)

6. P. N. Linnik, Ya. S. Ivanechko, R. P. Linnik., V. A. Zhezherya, Russ. J Gen. Chem., 83,13, 2715-2730 (2013)

7. P. N. Linnik, Ya. S. Ivanechko, R. P. Linnik., V. A. Zhezherya, J. Water Chem. Techno+, 35,6, 295-304 (2013)

8. Gonet S.: Struktura substancji humusowych. Zesz. Probl. Post. Nauk Roln., 411, 184-194 (1993)

9. M. Huculak-Mączka, K. Hoffmann, J. Skut, J. Hoffmann, Proceedings of ECOpole, 4, 2, 383-387 (2010)

10. S. Amir, M. Hafidi, L. Lemee, J. R. Bailly, G. Merlina, M. Kaemmerer., J. C. Revel, A. Ambles, J. Anal. Appl. Pyrolysis, 77, 149-158 (2006)

11. A.M. Anielak, M. Grzegorczuk-Nowacka, Pol. Environ. Stud., 20, 6, 1381-1386 (2011)

12. D. Łomińska, Czasopismo Techniczne, 1-Ś/2016, 80-81 (2016)

13. R. Świderska, A. M. Anielak, The significance of electrokinetic potential in the adsorption process of humic substances, Rocznik Ochrona Środowiska, 6, 31-49 (2004)

14. J. Pempkowiak, H. Obarska-Pempkowiak, M. Gajewska, D. Ruta, Przem. Chem., 87, 5, 542-54 (2008)

15. A. M. Anielak, M. Polus, D. Łomińska, T. Żaba, Przem. Chem., 95,1, 110- 113 (2016).

16. A. M. Anielak, T. Żaba, M. Polus, P. Beńko., T. Bochnia, Łuszczek B., Przem. Chem., 95 (2), 314-319 (2016)

17. D. Łomińska, A. M. Anielak, Płaszów WWTP as a source of humic acids, Leaving the Ivory Tower : bridging the gap between academia, industry, services and public sector : 8 th Eastern European Young Water Professionals Conference, Poland, Gdańsk (2016)

18. M. Grzegorczuk-Nowacka, Adsorpcja kwasów fulwowych z wodnych roztworów, praca doktorska, Kraków, 52-53 (2012)

19. B. Zhu, D. K. Ryan, J Environ. Radioactiv., 153, 97-103 (2016)

20. X. He, B. Xi, Z. Wei, X. Guo, M. Li, D. An, H. Liu, Chemosphere, 82, 541-548 (2011)

21. S. Huo, B. Xi, H. Yu, L. He, S. Fan, H. Liu, J. Eviron. Sci., 20, $492-498$ (2008).

22. W. Zieliński, A. Rajca, Metody spektroskopowe i ich zastosowanie do identyfikacji związków organicznych. Praca zbiorowa, WNT, Warszawa (2000)

23. Rocznik Statystyczny Rzeczypospolitej Polskiej (2016) 